\title{
Ari Finkelstein The Specter of the Jews: Emperor Julian and the Rhetoric of Ethnicity in Syrian Antioch
}

(Berkeley: University of California Press, 2018), hardcover, xvii + 251 pp.

\author{
H. A. DRAKE \\ drake@history.ucsb.edu \\ University of California, Santa Barbara, CA 93106
}

\begin{abstract}
"Specter" is an ominous word, calling to mind James Bond villains and things that go bump in the night. So it is a bit of a surprise to see it on a book about the fourth-century Roman emperor Julian's dealings with the Jews, which were fairly positive. Julian is, after all, the emperor who proposed to rebuild the Temple in Jerusalem, which had lain in ruins since the first century. But specter is just the right word for this book, because Ari Finkelstein's aim is to show how Julian constructed an image of "Judeans" that he could use to encourage his fellow Hellenes (the people we usually call "pagans") to oppose his former co-religionists, the Christians (who paid him back by labeling him "the Apostate").

Finkelstein's focus is on the nine months Julian spent in the eastern metropolis of Antioch, from July 362 to March 363. This was the longest period he stayed in any one place during the nineteen months of his brief reign as emperor (from December 361 to March 363). Finkelstein aims to make two inter-related points. First, he wants to show the prominent role played by Jews in this ancient city, where they had lived since its founding more than seven centuries earlier. Second, he emphasizes the influence of Julian's stay in Antioch on his thinking and his style of argumentation.

For both points, Finkelstein makes meticulous study of texts Julian wrote in Antioch, especially Against the Galileans (Julian's derogatory term for Christians), which Finkelstein describes as "ground zero" for understanding the emperor's relationship with Jews (p. 45). In the last part of that work, which survives only in fragments, Julian held up Judeans as examples not only to Christians (whom he painted as renegade Jews) but also to his fellow Hellenes. Given the long history of conflict between Jews and Greeks, why Julian did this is a complicated story, one that Finkelstein unpacks with great skill. His views rest on the intensive effort
\end{abstract}


made some forty years earlier by Bishop Eusebius of Caesarea to separate "Jews" from their "Hebrew" ancestors. By arguing that the patriarchs in Genesis lived prior to the emergence of Judaism, Eusebius could claim they were not just non-Jews but even proto-Christians. This stripped the Jews of their heritage and left them as "ghosts" that Julian could use later for his own purposes (p. 56). Another influence on Julian was Neoplatonism, whose adherents recognized the Jewish God, to the point of sometimes equating him with their own Creator God. But most important of all, Finkelstein argues, is the strong impression made on the emperor by the prominent and respected role played by Jews in Antioch's social, cultural, and religious life.

Finkelstein draws on a number of methodological approaches, including the ways that different groups' use of space define a city and shape communal identity. What most captures his attention is the growing body of scholarship dealing with ethnicity. The Roman empire, he writes, was "a world that defined itself ethnically," and one that defined an ethnos as a people that shared the same ancestral laws, the same god or gods, and, especially, the same land (p. 55). This explains Julian's preference for the term "Judeans," for this linked Jews to the land of Judea and provided them with a consistent historical record that "Galileans" could no longer usurp. It dovetailed with his concept of the empire as a collection of ethnicities presided over by a deity assigned to each of them by the Demiurge. Blood sacrifice was also a part of Julian's program, and the importance he attached to this ritual performed for the welfare of the empire partly explains his ambitious plan to rebuild the Temple in Jerusalem. Finkelstein devotes all of chapter six to this project, which is also treated in an appendix on the "Letter to the Community of Jews" attributed to Julian. While the authorship of the letter has been contested, Finkelstein concludes it has an authentic core that shows how Julian's plan to rebuild the Temple only took shape while he was writing Against the Galileans.

This chapter illustrates the strengths and the weaknesses of Finkelstein's laserlike focus on the influence of Antioch's Jews on Julian's thinking. After such an intensive discussion, readers might well want to know about the building project itself and the controversies around its aborted construction. However, such information is not directly linked with Finkelstein's project and so it is left out. Although we learn about the "ghost" of Judaism in chapter 3, the "specter" of the Jews does not appear until the last sentence of the book's conclusion ("Julian's resurrection of the specter of the Jews had serious unintended consequences" [p. 134]). In a similar way, the tantalizing mosaic discovered on the floor of a fourth-century synagogue in Hammat Tiberias only shows up in a footnote to p. 97, even though its depiction of the Sun god is used on the book's jacket. Finkelstein recognizes that Julian was raised a Christian and formally remained one into adulthood (p. 19). However, the Christian matrix of Julian's thinking, especially about the role of priests and the role of charity, is left out, even though he gives attention to the model of a Jewish priesthood (ch. 5).

All of these omissions are justifiable, and they contribute to the strength of Finkelstein's argument. At its core, his book is a study of texts and the power of 
texts, and the skill with which Finkelstein conducts it more than makes up for his inattention to topics that are discussed in just about any other study of Julian. 